\title{
Membangun Peta Pikiran pada Siswa dalam Belajar IPA Melalui Penerapan Metode Diskusi
}

\author{
ASNAWI \\ Dinas Pendidikan Kabupaten Kampar \\ J1. Kesehatan No. 1, Kode Pos : 28452 \\ E-mail : asnawismp4@yahoo.com
}

\begin{abstract}
Science learning has a fundamental function in generating and developing the ability to think critically, creatively and innovatively. In order for these goals to be achieved, the science needs to be taught in the right way and can actively involve students through scientific processes and attitudes. The quality of learning for science needs to be improved continuously to balance the development of technology. So that a teacher must be able to know the characteristics of students first. This classroom action research aims to describe the application of discussion methods in improving learning outcomes to create student mind maps. The location of this study was carried out at 1 Siak Hulu Public Middle School, based on observations in the field on science lessons found the phenomenon of achieving student learning outcomes less than KKM or said to have not succeeded. It is known that based on the pre-tests conducted on science subjects, especially students of class VIII.2 regarding mind maps of 33 students there were 28 people or $84.8 \%$ of students did not complete or smaller learning outcomes compared to the KKM set which was 78 . The research method used was Class action methods and research results show that the acquisition of learning outcomes through discussion of Cycle I, II and III individual completeness has only reached $15.2 \%$, then $39.40 \%$ and $97.0 \%$. The portrait of science learning has not yet achieved the goals expected by the teacher as contained in the performance indicators $>85 \%$ of the number of students in the class have achieved individual learning completeness. There is an increase in science learning outcomes in the material making mind maps in class VIII science lessons in SMP N 1 Siak Hulu by applying discussion methods so that learning outcomes have increased.
\end{abstract}

Keywords: Student Mind Mapping, Discussion Method

Peningkatan kualitas pendidikan harus dipenuhi melalui peningkatan kualitas dan kesejahteraan pendidik dan tenaga kependidikan lainnya. Pembaharuan kurikulum yang sesuai dengan perkembangan ilmu pengetahuan dan teknologi tanpa mengesampingkan nilainilai luhur sopan santun dan etika serta didukung penyediaan sarana dan prasarana yang memadai, karena pendidikan yang dilaksanakan sedini mungkin dan berlangsung seumur hidup menjadi tanggung jawab keluarga, sekolah, masyarakat dan pemerintah.

Tugas utama guru adalah mengelola proses belajar dan mengajar, sehingga terjadi interaksi aktif antara guru dengan siswa, dan siswa dengan siswa. Interaksi tersebut sudah pasti akan mengoptimalkan pencapaian tujuan yang dirumuskan Tujuan utama pembelajaran Ilmu Pengetahuan Alam (IPA) adalah agar siswa memahami konsep-konsep IPA secara sederhana dan mampumenggunakan metode ilmiah, bersikap ilmiah untuk memecahkan masalah-masalah yang dihadapi dengan lebih menyadari kebesaran dan kekuasaan pencipta alam (Depdikbud, 1997).

Pembelajaran IPA memiliki fungsi yang fundamental dalam menimbulkan serta mengembangkan kemampuan berpikir kritis, kreatif dan inovatif. Agar tujuan tersebut dapat tercapai, maka IPA perlu diajarkan dengan cara yang tepat dan dapat melibatkan siswa secara aktif yaitu melalui proses dan sikap ilmiah. Mutu pembelajaran IPA perlu ditingkatkan secara berkelanjutan untuk mengimbangi perkembangan teknologi. Sehingga seorang guru harus dapat 
mengetahui karakteristik peserta didik terlebih dahulu.

Peningkatan kualitas pendidikan dapat dicapai apabila kegiatan pelayanan pada proses belajar mengajar di kelas dapat dikelola dan berlangsung dengan baik berdaya guna berhasil guna. Hal tersebut dapat dilaksanakan apabila ditunjang dengan adanya rencana, pelaksanaan, pengawasan dan penilaian dari pimpinan atau kepala sekolah lembaga pendidikan tersebut. Selain itu juga upaya peningkatan kemampuan dan kualitas guru sangat diperlukan seperti dengan memberikan dorongan atau motivasi serta memberikan perhatian yang lebih. Kemudian kelengkapan sarana dan prasarana dalam menunjang proses belajar mengajar juga ikut berkontribusi serta yang tak kalah penting adalah kepemimpinan kepala sekolah dalam mengelola sekolahnya.

Sebab merekalah sebagai pelaksana terdepan atau ujung tombak terlaksananya kegiatan belajar mengajar di sekolah. Berhasil atau tidaknya upaya peningkatan mutu pendidikan banyak ditentukan oleh kompetensi yang ada pada mereka tersebut dalam mengembangkan tugas pokok seharihari. Guru dengan jenis pekerjaan ini tidak dapat dilaksanakan kebanyakan orang di luar pendidikan. Keahlian khusus yang dimaksud adalah upaya penanganan yang lebih spesifik dan perlunya kecermatan yang mendalam. Hal ini dapat dilihat dari beberapa tugas guru diantaranya mendidik, mengajar dan melatih. Mendidik berarti meneruskan dan mengembangkan nilainilai hidup, kemudian mengajar berarti meneruskan dan mengembangkan ilmu pengetahuan dan teknologi, selanjutnya melatih berarti mengembangkan keterampilan melalui minat, bakat dan kreativitas. Namun pada kenyataannya masih saja ada berbagai kendala, kelemahan dan kekurangan guru didalam menjalankan tugas sebagai profesi.

Seorang guru menyadari bahwa titik pusat tujuan sekolah menyediakan program pendidikan yang direncanakan untuk memenuhi kebutuhan hal-hal yang berkaitan dengan pendidikan, pribadi dan kebutuhan kemasyarakatan serta kepentingan individu para siswa. Siswa merupakan klien utama yang harus dilayani, oleh sebab itu siswa harus dilibatkan secara aktif dan tepat, tidak hanya dalam proses belajar mengajar melainkan juga di dalam kegiatan sekolah.

Perubahan yang makin meningkat mengakui bahwa guru secara individual harus mendapatkan perhatian. Terdapat banyak hal yang perlu mendapatkan perhatian dari seorang guru, seperti masalah kompetensinya. Berbicara masalah kompetensi guru saat ini menjadi hal yang menarik. Banyak persoalan tentang kompetensiguru dalam memberikan pelayanan pendidikan kepada peserta didik, seperti persoalan dunia kerja guru yang memberikan pengajaran, guru dengan pimpinannya, kemudian persoalan guru dengan muridnya, guru dengan lingkungannya juga menjadi masalah tersendiri yang ikut menentukan mutu pendidikan.

Guru yang mengajar di sekolah menengah pertama memerlukan kesiapan yang ekstra, karena pada fase umur remaja (tingkat SMP) siswa baru mengalami fase perubahan. Sekolah Menengah Pertama (SMP) adalah salah satu lembaga pendidikan yang bertugas untuk menyelenggarakan pendidikan formal di tingkat menengah. Sekolah menengah diselenggarakan untuk melanjutkan ke jenjang berikutnya dan menyiapkan peserta didik menjadi anggota masyarakat yang memiliki kemampuan mengadakan interaksi dengan lingkungan sosial, budaya dan alam sekitar serta dapat mengembangkan kemampuan dan keterampilan lebih lanjut kedalam dunia kerja.

Lokasi penelitian ini dilakukan di SMP Negeri 1 Siak Hulu, berdasarkan pengamatan di lapangan pada pelajaran IPA ditemukan fenomena pencapaian hasil belajar siswa kurang dari KKM atau dikatakan belum berhasil. Diketahui 
bahwa berdasarkan pre tes yang dilakukan pada mata pelajaran IPA khususnya siswa kelas VIII.II mengenai peta pikiran dari 33 siswa terdapat 28 orang atau $84.8 \%$ siswanya tidak tuntas atau lebih kecil hasil belajarnya dibandingkan dengan KKM yang ditetapkan yakni 78 .

Selain itu juga masalah yang dihadapi siswa adalah, siswa kurang memahami akan makna pelajaran membuat peta pikiran dalam kehidupan sehari-hari dan juga kurang mampu menghafal rumusrumus yang ada pada peta pikiran, kesulitan menghafal dan memahami pelajaran menjadi kendala tersendiri bagi siswa dalam mengikuti pelajaran IPA tersebut dan siswa cenderung bingung dalam mengikuti pelajaran yang diberikan.

Kemudian sikap siswa dalam belajar cenderung pasif dalam mengikuti pelajaran, dimana pada saat guru meminta siswa bertanya atau menanggapi pelajaran yang diberikan siswa cenderung diam saja dan juga pada saat guru bertanya kepada siswa, siswa malahan ketakutan menjawabnya. Selain itu juga siswa kurang semangat mengikuti materi pelajaran yang diberikan dan berusaha untuk mencari alasan untuk tidak mengikutinya.

Berdasarkan uraian pada latar belakang masalah tersebut di atas, maka penulis tertarik membuktikannya dalam sebuah penelitian dengan perumusan masalah dalam penelitian ini adalah apakah penerapan metode diskusi dapat meningkatkan hasil belajar membuat peta pikiran pada pelajaran IPA kelas VIII.II SMP N 1 Siak Hulu Tahun Ajaran 20152016.

Untuk menghindari salah pengertian atau salah tafsir tentang makna istilah yang digunakan dalam penelitian ini, maka perlu dijelaskan makna beberapa definisi operasional sebagai berikut : Hasil belajar peranan membuat peta pikiran adalah pencapaian yang diperoleh siswa setelah mengikuti pelajaran yakni memahami membuat peta pikiran. Metode diskusi merupakan sebuah kelompok model pembelajaran yang melibatkan siswa bekerja secara berkolaborasi untuk mencapai tujuan bersama.

Konsep hasil belajar adalah harus memperoleh kecakapan dan pengetahuan dari sekolah, di samping mengembangkan pribadinya. Pemberian kecakapan dan pengetahuan kepada siswa, yang merupakan proses belajar-mengajar dilakukan oleh guru di sekolah dengan menggunakan cara-cara atau metodemetode tertentu (Suryosubroto, 1997).

Dalam dalam sistem pendidikan nasional rumusan tujuan pendidikan, baik tujuan kurikuler maupun tujuan instraksional, menggunakan klasikfikasi hasil belajar dari Benyamin Bloom yang secara garis besar membaginya menjadi tiga ranah yakni ranah kognitif, ranah efektif, dan ranah pisikmotoris (Nana Sudjana, 2005).

Menurut Koswara (2008) menyatakan bahwa kompetensi guru dapat dimaknai sebagai gambaran tentang apa yang seyogyanya dapat dilakukan seseorang guru dalam melaksanakan pekerjaannya, baik berupa kegiatan, berperilaku maupun hasil yang dapat ditunjukkan. Inti dari pendidikan adalah interaksi antara guru dengan siswa dalam mencapai tujuan-tujuan pendidikan. Guru, siswa dan tujuan pendidikan adalah komponen-komponen pendidikan yang utama (esencial). Menurut Syaiful Sagala (2009) kompetensi guru adalah seperangkat pengetahuan, ketrampilan dan perilaku yang harus dimiliki, dihayati dan dikuasai oleh guru dalam melaksanakan tugas keprofesionalan.

Kemudian menurut Arni Muhammad dan Ilyas (2005) ketiga komponen pendidikan ini membentuk suatu segitiga, yang jika hilang salah satu komponennya, maka akan hilanglah hakekat dari pendidikan. Sebagai seorang pendidik, tugas guru pada dasarnya adalah mendidik, yaitu membantu anak didik mengembangkan pribadinya, memperluas pengetahuannya, dan melatih keterampilannya dalam berbagai bidang.Untuk dapat melaksanakan tugas 
tersebut seorang guru harus memiliki sejumlah kemampuan, yang sering disebut dengan kompetensi profesional.

Usman (2002) memberikan pengertian kompetensi guru dengan kemampuan dalam melaksanakan kewajiban-kewajiban secara bertanggung jawab dan layak. Dari sisi lain berkaitan dengan kompetensi Prayitno (2002) mengatakan bahwa: Kompetensi merupakan pengetahuan, keterampilan, nilai, sikap dasar yang direfleksikan dalam kebiasaan berpikir dan bertindak yang bersifat dinamis, berkembang, dan dapat diraih setiap waktu. Kebiasaan berpikir dan bertindak secara konsisten dan terus menerus memungkinkan seseorang menjadi kompeten, dalam arti memiliki pengetahuan, keterampilan, nilai, dan sikap sikap dasar dalam melakukan sesuatu.

Dari pendapat para ahli di atas dapat disimpulkan bahwa kompetensi adalah karakteristik kemampuan individu yang dimiliki untuk melakukan dan memutuskan sesuatu kegiatan tertentu.Kemampuan tersebut terlihat dalam kegiatan berfikir dan bertindak yang dilakukan secara konsisten.

Proses belajar dan hasil belajar para siswa bukan saja ditentukan oleh sekolah, pola, stuktur, dan isi kurikulumnya, akan tetapi sebahagian besar ditentukan oleh kompetensi guru yang mengajar dan membimbing mereka. Guru yang kompeten akan lebih mampu menciptakan lingkungan belajar yang efektif, menyenangkan, dan akan mampu mengelola kelasnya, sehingga belajar siswa pada tingkat optimal. Berdasarkan pertimbangan dan analisis di atas, dapat diperoleh gambaran secara fundamental tentang pentingnya kompetensi guru.

Oemar Hamalik (2002) menyebutkan kompetensi guru dalam jenjang pendidikan apapun meliputi kompetensi profesional, kompetensi kepribadian, dan kompetensi kemasyarakatan. Secara teoretis ketiga kompetensi ini dapat dipisah-pisahkan satu dengan yang lain, akan tetapi secara praktis sesungguhnya ketiga jenis kompetensi ini tidak dapat dipisah-pisahkan. Ketiga kompetensi ini saling menjalin secara terpadu dalam diri guru.Guru yang terampil mengajar tentu harus memiliki pribadi yang baik dan mampu melakukan social adjustment dalam masyarakat, ketiga kompetensi ini terpadu dalam karakteristik tingkah laku guru.

Menurut Imron (2003) bahwa pakar pendidikan seringkali menegaskan bahwa guru merupakan sumberdaya manusia yang sangat menentukan keberhasilan program pendidikan.Apapun yang telah dilakukan untuk meningkatkan mutu pendidikan yang pasti peningkatan mutu pendidikan tidak mungkin ada tanpa kualitas performa gurunya. Oleh karena itu peningkatan performa guru mutlak harus dilakukan secara terus menerus dalam rangka meningkatkan mutu pendidikan di sekolah.

Slameto (1995) menyebutkan bahwa: "mengajar adalah kegiatan mengorganisasi yang bertujuan untuk membantu dan menggairahkan siswa belajar". Mengajar dapat diartikan sebagai proses menyampaikan pengetahuan dan kecakapan tertentu kepada anak didik. Yang lain menyebutkan bahwa mengajar adalah mengorganisasi lingkungan secara kondusif sehingga dapat menciptakan kondusif kepada siswa untuk melakukan proses belajar secara efektif.

$\begin{array}{llr} & \text { Mengajar merupakan aktifitas } \\ \text { yang dilakukan oleh guru dalam } & \end{array}$ Aktivitas guru dilakukan secara bertahap, diawali dengan menyusun perencanaan secara menyeluruh tentang segala sesuatu yang akan dilakukan pada saat terjadi interaksi dengan siswa dan pemanfaatan sumber-sumber yang ada untuk mendukung selama kegiatan yaitu melakukan evaluasi, menganalisis dan melakukan pencatatan-pencatratan terhadap sesuatu yang terjadi pada saat interaksi berlangsung.

Pada saat terjadi interaksi dengan siswa, maka guru memilih dan melakukan dengan cara-cara tertentu agar kegiatan 
interaksi dengan siswa dapat berjalan dengan kondusif sehingga tujuan yang diharapkan dapat tercapai.Cara-cara yang dilakukan oleh guru dalam melakukan interaksi dengan siswa disebut metode mengajar.

Metode mengajar memiliki peranan yang sangat penting dalam proses belajar mengajar. Soetomo (1993) menyebutkan: "metode mengajar sebagai suatu alat untuk mencapai tujuan pengajaran yang ingin dicapai, sehingga semakin baik penggunaan metode mengajar semakin berhasillah pencapaian tujuan. Penggunaan metode mengajar secara tepat dapat menumbuhkan minat siswa untuk dapat mengikuti kegaitan belajar mengajar dengan baik, sehingga kreatifitas anak akan muncul dan berkembang dengan baik pula. Namun sebaliknya, jika penggunaan metode mengajar ini kurang tepat, maka akan menjadi tidak bermakna bahkan dapat mematikan kreatifitas siswa.

Penelitian metode mengajar sangat tergantung pada sutuasi dan kondisi yang saat guru mengajar.Tidak semua metode mengajar selalu tepat digunakan untuk menyampaikan materi pelajaran. Metode mengajar sangat banyak ragamnya, antara lain: metode ceramah, metode Tanya jawab, metode diskusi, metode pemberian tugas, metode bermain peran, metode inkuiri, metode demonstrasi, metode pemecahan masalah. Berbagai metode tersebut memiliki kelebihan dan kekurangannya masing-masing.

Slavin (1995) mengatakan bahwa pembelajaran diskusi adalah pembelajaran dimana siswa dalam berkelompok kecil yang terdiri dari 4-6 siswa belajar dan bekerja secara kolaboratif, dengan struktur kelompok yang heterogen. Secara garis besarnya pembelajaran diskusi mengandung arti mengerjakan sesuatu secara bersama-sama dengan saling membantu satu sama lainnya sebagai satu kelompok atau satu tim. Arends (dalam Trianto, 2007) menyatakan bahwa pembelajaran diskusi mempunyai ciri-ciri sebagai berikut. a. Siswa bekerja dalam kekompok secara diskusi untuk menuntaskan materi belajar;

b. Kelompok dibentuk dari siswa yang mempunyai kemampuan tinggi, sedang dan rendah;

c. Bila memungkinkan, anggota kelompok berasal dari ras, budaya, suku, jenis kelamin yang beragam; dan

d. Penghargaan lebih berorientasi pada kelompok dari pada individu.

Carry (dalam Agus dan Rosmaini, 2006) mengemukakan ciri-ciri pembelajaran diskusi sebagai berikut.

a. Setiap anggota memiliki peran;

b. Terjadinya hubungan interaksi langsung diantara siswa;

c. Setiap anggota kelompok bertanggung jawab atas belajarnya sendiri dan teman-teman kelompoknya;

d. Peran guru membantu siswa untuk mengembangkan keterampilanketerampilan interpersonal kelompok; dan

a. Guru hanya berinteraksi dengan kelompok saat diperlukan.

Cilibert-Macmilan (dalam Agus dan Rosmaini, 2006) mengatakan bahwa pembelajaran diskusi bertujuan memberi peluang kepada siswa agar mengemukakan dan membahas suatu pandangan, pengetahuan yang diperoleh siswa belajar secara bekerjasama dalam merumuskan kearah satu pandangan kelompok. Sedangkan Trianto (2007) mengatakan pembelajaran diskusi disusun dalam suatu usaha untuk meningkatkan partisipasi siswa, memfasilitasi siswa dengan pengalaman sikap kepemimpinan dan membuat keputusan dalam kelompok serta memberikan kesempatan pada siswa untuk berinteraksi dan diskusi -sama siswa yang berbeda latar belakangnya. Pembelajaran diskusi merupakan sebuah kelompok model pembelajaran yang melibatkan siswa bekerja secara berkolaborasi untuk mencapai tujuan 
bersama (Eggen dan Kauchak dalam Trianto, 2007). Ibrahim (2000) menyatakan, model pembelajaran diskusi dikembangkan untuk mencapai tiga tujuan yang sangat penting, yaitu :hasil belajar akademik;penerimaan terhadap perbedaan individu; danpengembangan keterampilan sosial.

Berdasarkan pendapat di atas tujuan utama dalam pembelajaran diskusi adalah agar peserta didik dapat belajar secara berkelompok bersama teman-temannya dengan cara saling menghargai pendapat dan memberi kesempatan kepada orang lain untuk mengemukakan gagasannya dan menyampaikan pendapat mereka secara berkelompok.Agar tercapai tujuan pembelajaran diskusi diatas dan unggul dalam membantu siswa memahami konsepkonsep sulit, membantu siswa menumbuhkembangkan kemampuan kerjasama perlu ditetapkan langkah pembelajaran diskusi. Kegiatan tersebut terdiri dari beberapa langkah.

Trianto (2007) menyatakan bahwa pembelajaran diskusi tipe STAD ini merupakan salah satu tipe dari model pembelajaran diskusi dengan menggunakan kelompok-kelompok kecil dengan jumlah anggota tiap kelompok 4-5 orang siswa secara heterogen. Selanjutnya Slavin (dalam Trianto, 2007) menyatakan bahwa pada STAD siswa ditempatkan dalam tim belajar beranggotakan 4-5 orang yang merupakan campuran menurut tingkat prestasi, jenis kelamin, dan suku. Guru menyajikan pelajaran, kemudian siswa bekerja dalam tim mereka dan memastikan bahwa seluruh anggota tim telah menguasai pelajaran tersebut. Kemudian, pada waktu tertentu seluruh siswa diberikan tes tentang materi tersebut, pada saat tes ini siswa tidak diperbolehkan saling membantu.

Pelaksanaan pembelajaran diskusi tipe STAD dalam proses pembelajaran melalui tahap persiapan, penyajian kelas, kegiatan kelompok, melaksanakan evaluasi, penghargaan kelompok dan menghitung ulang skor awal serta perubahan kelompok. Menurut Slavin (1995) langkah-langkah pembelajaran diskusi tipe STAD melalui tahap-tahap sebagai berikut.

Pada tahap ini disiapkan materi yang akan disajikan dalam pembelajaran, menentukan skor awal siswa dan membagi siswa ke dalam kelompok diskusi. Materi yang akan disajikan dalam pembelajaran diskusi tipe STAD dirancang sedemikian rupa sehingga sesuai dengan bentuk pembelajaran secara kelompok. Sebelum menyajikan materi pembelajaran, terlebih dahulu dibuat lembar kerja siswa yang akan dipelajari siswa di dalam kelompok-kelompok diskusi . Trianto (2007) mengemukakan bahwa persiapan-persiapan pembelajaran diskusi tipe STAD sebagai berikut.

1) Perangkat Pembelajaran. Sebelum melaksanakan kegiatan pembelajaran perlu dipersiapkan perangkat pembelajarannya. Perangkat pembelajaran tersebut meliputi Silabus, Rencana Pelaksanaan Pembelajaran (RPP) dan Lembar Kerja Siswa (LKS).

2) Menentukan Kelompok Diskusi . Menentukan anggota dalam kelompok diusahakan agar kemampuan siswa dalam kelompok adalah heterogen dan kemampuan antar satu kelompok dengan kelompok lainnya relatif homogen. Apabila memungkinkan kelompok diskusi perlu memperhatikan ras, agama, jenis kelamin, dan latar belakang sosial.

3) Menentukan Skor Awal. Skor awal yang dapat digunakan dalam kelas koopertif adalah skor ulangan sebelumnya. Skor awal dapat berubah setelah ada kuis. Misalnya pada pembelajaran lebih lanjut dan setelah diadakan tes, maka hasil tes masingmasing individu dapat dijadikan skor awal.

4) Pengaturan Tempat Duduk. Pengaturan tempat duduk dalam kelas diskusi perlu juga diatur dengan baik. Pengaturan tempat duduk yang baik dapat menunjang keberhasilan pembelajaran diskusi .

E-ISSN:2598-6449 P-ISSN : 2580-4111 Vol. 2, No. 2, Agustus 2018 
5) Tahap Penyajian Kelas. Tahap penyajian kelas terdiri dari kegiatan awal, kegiatan inti dan kegiatan penutup.

6) Memberi Penghargaan. Berdasarkan skor perkembangan kelompok yang diperoleh terdapat tiga tingkat kriteria penghargaan yang diberikan. (Slavin, 1995) menyatakan guru boleh memberikan penghargaan kelompok

Selanjutnya (Slavin, 1995) menyatakan bahwa guru boleh mengubah kriteria. Jika $\bar{x}$ menyatakan rata-rata skor kelompok, maka dalam penelitian ini, peneliti menggunakan kriteria penghargaan kelompok.

\section{METODE}

Metode penelitian yang digunakan adalah metode penelitian tindakan kelas. Suroto (2017). Prosedur penelitian tindakan kelas yakni: 1) perencanaan (planning), 2) tindakan (acting), 3) pengamatan (observing), dan 4) refleksi (reflecting). Lokasi penelitian ini dilakukan di SMP Negeri 1 Siak Hulu, berdasarkan pengamatan di lapangan pada pelajaran IPA ditemukan fenomena pencapaian hasil belajar siswa kurang dari KKM atau dikatakan belum berhasil. Diketahui bahwa berdasarkan pre tes yang dilakukan pada mata pelajaran IPA khususnya siswa kelas VIII.2 mengenai peta pikiran dari 33 siswa terdapat 28 orang atau $84.8 \%$ siswanya tidak tuntas atau lebih kecil hasil belajarnya dibandingkan dengan KKM yang ditetapkan yakni 78. Teknik pengumpulan data dengan melakukan penyebaran kuesioner pre tes dan pos tes. Analisis data dalam penelitian tindakan kelas ini menggunakan analisis kuantitatif dan kualitatif (Supardi, 2006:131).Terhadap perolehan hasil belajar IPA dianalisis secara kuantitatif dengan memberikan nilai pada hasil belajar siswa.Data-data tersebut dianalisis mulai dari siklus satu sampai dengan siklus tuga untuk dibandingkan dengan teknik deskriptif presentase.

\section{HASIL}

Telah diketahui bahwa subjek penelitian berjumlah 33 siswa. Pelaksanaan penelitian tindakan kelas ini dilakukan dalam 3 (tiga) siklus, yakni siklus I. Berikut disajikan paparan hasil penelitian yang terdiri atas hasil belajar IPA melalui kolaborasi model pembelajaran diskusi dan hasil observasi terhadap proses pembelajaran.

\section{Siklus I}

Berdasarkan data hasil penelitian siklus I mengenai hasil belajar IPA materi pokok membuat peta pikiran, melalui model pembelajaran diskusi diperoleh data untuk ketuntasan 78 sebanyak $15.2 \%$ atau 5 orang siswa. Sedangkan yang tidak tuntas sebesar 28 atau $84.8 \%$, dan rata-rata hasil belajar sebesar 76. Selengkapnya dapat dibaca pada tabel distribusi frekuensi bergolong sesuai dengan kategori hasil belajar menunjukkan bahwa perolehan hasil belajar melalui diskusi Siklus I ketuntasan individual baru mencapai $15.2 \%$. Potret pembelajaran IPA belum mencapai tujuan yang diharapkan guru yang tertuang dalam indikator kinerja $>85 \%$ dari jumlah siswa dalam kelas telah mencapai ketuntasan belajar individual, sehingga perlu dilaksanakan siklus II.

\section{Siklus II}

Berdasarkan data hasil penelitian siklus I mengenai hasil belajar IPA materi pokok membuat peta pikiran, melalui model pembelajaran diskusi diperoleh data untuk ketuntasan 78 sebanyak 13 orang siswa tuntas atau $39.4 \%$. Sedangkan yang tidak tuntas sebesar 20 atau $60.6 \%$ dan ratarata hasil belajar sebesar 78 . Selengkapnya dapat dibaca pada tabel distribusi frekuensi bergolong sesuai bahwa perolehan hasil belajar melalui diskusi Siklus II ketuntasan individual 39.4\%.Potret pembelajaran IPA sudah mencapai tujuan yang diharapkan guru yang tertuang dalam indikator kinerja $>85 \%$ dari jumlah siswa dalam kelas telah mencapai ketuntasan belajar individual, sehingga untuk kesempurnaan perlu 
dilaksanakan siklus III.

\section{Siklus III}

Berdasarkan data hasil penelitian siklus I mengenai hasil belajar IPA materi pokok membuat peta pikiran, melalui model pembelajaran diskusi diperoleh data untuk ketuntasan 78 sebanyak 33 orang siswa tuntas atau $97.0 \%$. dan rata-rata hasil belajar sebesar 80. Selengkapnya dapat dibaca pada tabel distribusi frekuensi bergolong sesuai bahwa perolehan hasil belajar melalui diskusi Siklus III ketuntasan individual mencapai 97.0\%. Potret pembelajaran IPA sudah mencapai tujuan yang diharapkan guru yang tertuang dalam indikator kinerja $>85 \%$ dari jumlah siswa dalam kelas telah mencapai ketuntasan belajar individual, sehingga sudah perlu dapat diakhiri penelitian ini.

Hasil observassi pada siklus III diperoleh gambaran tentang sikap disiplin (discipline) dalam belajar dengan menghargai waktu belajar dan juga petunjuk belajar yang diberikan sudah baik, kemudian memiliki rasa hormat kepada guru dan sesama rekan belajar dalam berdiskusi dan perhatian (respect) terhadap berbagai pertanyaan dan perubahan yang terjadi dengan mengkritisinya sudah baik serta tekun (diligence) dalam menyelesaikan tugas yang diberikan guru di kelas baik, tanggung jawab (responsibility) terhadap tugas yang diberikan dalam bentuk menyelesaikan tugas dan ketelitian (carefulness) dalam menyelesaikan tugas sesuai dengan fakta materi yang diberikan juga baik.

Dari sudut guru kemampuan mengajar guru sudah baik, ada peningkatan yang signifikan. Guru sudah baik dalam mengelola ruang, fasilitas, strategi, interaksi dengan siswa, dan evaluasi dengan baik juga untuk pengelolaan waktu sudah dapat terlaksana dengan efektif, karena guru sudah terbiasa menggunakan model pembelajaran. Kesan umum guru dalam mengajar sudah luwes dan sudah peka dengan kondisi siswa.

\section{PEMBAHASAN}

Berdasarkan hasil penelitian diketahui bahwa terdapat peningkatan hasil belajar IPA materi membuat peta pikiran yang dilaksanakan di SMP Negeri 1 Siak Hulu, berdasarkan pengamatan di lapangan pada pelajaran IPA ditemukan fenomena pencapaian hasil belajar siswa kurang dari KKM atau dikatakan belum berhasil. Diketahui bahwa berdasarkan pre tes yang dilakukan pada mata pelajaran IPA khususnya mengenai peranan usaha, gaya dan energi dalam kehidupan sehari-hari dari 30 siswa terus mengalami peningkatan pada siklus pertama yakni mulai $15.2 \%$, kemudian $39.40 \%$ dan $97.0 \%$ pada siklus berikutnya

Kemudian sikap siswa dalam belajar cenderung pasif dalam mengikuti pelajaran, dimana pada saat guru meminta siswa bertanya atau menanggapi pelajaran yang diberikan siswa cenderung diam saja dan juga pada saat guru bertanya kepada siswa, siswa malahan ketakutan menjawabnya. Selain itu juga siswa kurang semangat mengikuti materi pelajaran yang diberikan dan berusaha untuk mencari alasan untuk tidak mengikutinya.

Dengan penerapan metode diskusi, diperoleh melalui langkah-langkah: guru membimbing peserta didik dalam pembentukan kelompok, peserta didik (dibimbing oleh guru) mendiskusikan membuat peta pikiran, peserta didik dalam setiap kelompok mendiskusikan membuat peta pikiran, perwakilan dari tiap kelompok diminta untuk mempersentasikan hasil diskusi, guru menangapi hasil diskusi kelompok peserta didik dan memberikan informasi yang sebenarnya. Peserta didik memperhatikan contoh soal penerapan membuat peta pikiran yang disampaikan oleh guru, guru memberikan beberapa soal membuat peta pikiran untuk dikerjakan oleh peserta didik, guru mengoreksi jawaban peserta didik apakah sudah benar atau belum.

\section{SIMPULAN}

Berdasarkan hasil penelitan yang telah dilaksanakan, maka dapat ditarik beberapa kesimpulan sebagai berikut: Perolehan hasil belajar melalui diskusi 
Siklus I, II dan III ketuntasan individual baru mencapai $15.2 \%$, kemudian $39.40 \%$ dan 97.0\%. Potret pembelajaran IPA belum mencapai tujuan yang diharapkan guru yang tertuang dalam indikator kinerja $>85 \%$ dari jumlah siswa dalam kelas telah mencapai ketuntasan belajar individual. Terdapat peningkatan hasil belajar IPA materi membuat peta pikiran pada pelajaran IPA kelas VIII SMP N 1 Siak Hulu dengan menerapkan metode diskusi sehingga hasil belajar mengalami peningkatan.

\section{DAFTAR RUJUKAN}

Agus, D., dan Rosmaini, S., 2006, Strategi Pembelajaran Sains di Sekolah Dasar, Cindikia Insani, Pekanbaru.

Arni,Muhammad, 2005, Komunikasi Organisasi, Jakarta : Bumi Aksara

Depdikbud. (1997). Kamus Besar Bahasa Indonesia. Jakarta: Balai Pustaka.

Ibrahim.,Muslimin., dan Nur, M., 2000, Pembelajaran Diskusi, Universitas Negeri Surabaya, Surabaya.

Imron, Ali,. Maisyaroh,. Burhanuddin, 2003, Manajemen Pendidikan. Analisis Substantif dan Aplikasinya dalam Institusi Pendidikan, Universitas Negeri Malang, Malang.

Koswara, Deni dan Halimah, 2008, Bagaimana Menjadi Guru Kreatif?, Pribumi Mekar, Bandung.

Nana Sudjana. 2005. Metode Statistika, Bandung: Tarsito.

Oemar Hamalik, 2002, Pendidikan Guru: Berdasarkan Pendekatan Kompetensi. Jakarta: Bumi Aksara.

Prayitno. 2002, Dasar-Dasar Bimbingan dan Konseling, Jakarta. Rhineka Cipta
Slameto, 1995. Belajar dan faktor-faktor yang Mempengaruhinya, Jakarta : Rineka Cipta

Slavin, R.E., 1995, Cooperative Learning Theory, Research and Practice, Allynd Bacon, Boston.

Soetomo. (1993). Dasar-Dasar Interaksi Belajar Mengajar. Cetakan Ke-1. Surabaya: Usaha Nasional.

Suroto, B., Novita, N., Pailis, E. A., Waldelmi, I., \& Fatkhurahman, F. (2017). Metode Penelitian Tindakan Solusi Bagi Masalah Sosial. Jurnal Diklat Review, 1(1), 25-28.

Suryosubroto. 1997. Proses Belajar Mengajar Di Sekolah. (Jakarta: PT. Rineksa Cipta).

Syaiful Sagala, 2009, Kemampuan Profesional Guru dan Tenaga Kependidikan, Alfabeta, Bandung.

Trianto., 2007, Model-model Pembelajaran Inovatif Berorientasi Konstruktivistik, Prestasi Pustaka, Jakarta.

Usman, 2002, Menjadi Guru Profesional, Remaja Rosdakarya, Bandung 